\title{
THE EFFECT OF EXTRACT OF DATE PALM FRUIT (PHOENIX DACTYLIFERA L.) ON FERTILITY IN MALE MICE (MUS MUSCULUS L.)
}

\section{DWISARI DILLASAMOLA ${ }^{1 *}$, ALMAHDY A ${ }^{1}$, FENI ELFIANITA ${ }^{1}$, SKUNDA DILIAROSTA ${ }^{2}$, BIOMECHY OKTOMALIO P ${ }^{3}$ NOVERIAL NOVERIAL ${ }^{3}$}

${ }^{1}$ Department of Pharmacy, Faculty of Pharmacy, Andalas University, Padang, Indonesia. ${ }^{2}$ Department of Biology, Faculty of Math and Science, United of State, Padang, Indonesia. ${ }^{3}$ Department of Medicine, Faculty of Medicine, Andalas University, Padang, Indonesia. Email: dwisaridillasamola@phar.unand.ac.id

Received: 01 September 2018, Revised and Accepted: 26 November 2018

ABSTRACT

Objective: Date palm is one of the plants that have used empirically to increase fertility. Ethanol induction can cause sperm damage in male mice. Sperm damage is one of the infertility agents. The aim of this study was to observe and determine anti-infertility effects of the ethanol extract of date palm fruit in khalal stage in male mice compared with propolis.

Methods: A total of 5 groups were assigned to 1 control and 4 experimental groups. Control group was treated by intraperitoneal administration of ethanol only. Meanwhile, experimental groups was treated by intraperitoneal administration of ethanol induction and oral administration of 140 , 280 , and $560 \mathrm{mg} / \mathrm{kg} \mathrm{BW}$ of khalal date fruit extract and $1400 \mathrm{mg} / \mathrm{kg} \mathrm{BW}$ of propolis for 34 days. At $35^{\text {th }}$ day, the mice were deeply anesthetized with anesthetic ether and sacrificed. Laparotomy was performed to collect sperms from epididymis and testes for determining testis weight to analyze the sperm. The data were analyzed using one-way ANOVA and Duncan's test.

Results: The result of the research showed that there were more anti-infertility activity of ethanol extract of date palm fruit in khalal stage ( $<0.05$ ) on sperm count, motility of sperm, and weight of testes in male white mice toghether with larger doses administration. The optimum activity was accepted by the administration of doses $560 \mathrm{mg} / \mathrm{kg} \mathrm{BW}$.

Conclusion: Ethanol extract of khalal date fruit and propolis can increase the quality of sperm pervade sperm count, sperm motility, and weight of testes. Ethanol extract of khalal date fruit can increase sperm quality higher than propolis.

Keywords: Date palm, Propolis, Fertility, Spermatozoa, Vas deferens, Testes.

(C) 2019 The Authors. Published by Innovare Academic Sciences Pvt Ltd. This is an open access article under the CC BY license (http://creativecommons. org/licenses/by/4. 0/) DOI: http://dx.doi.org/10.22159/ajpcr.2019.v12i1.29453

\section{INTRODUCTION}

Infertility is defined as the failure to achieve a clinical pregnancy after a minimum of 12 months or longer of regular unprotected sexual intercourse [1]. Infertility is a very sensitive and difficult issue for married couples, especially those who have been married for a long time. Nowadays, infertility has increased with $64 \%$ cases in female and $36 \%$ in male. In the fertile couples, infertility could reach $10-20 \%$ of cases [2]. Approximately $15 \%$ of couples were no pregnant in 2 years and $14 \%$ in 3 years [3]. Based on the World Health Organization assessment, the infertility case is going to increase significantly in the future for about 2 million cases [2]

There were many factors which cause infertility, and one of them is the male factor. Infertility in male contributed to determine the ability of the couple to had offspring. Estimately, 7\% from all males has infertility problem. Infertility occurs due to the disruption of sperm production and testicular disturbance in releasing sperm or directly caused by low quality of sperm. Disruption of production, quality, and transportation of sperm are the factors that determine the quality of sperm to reach the ovum, penetrate to the egg membrane, and whether fertilization occurs or not. The ability of the male to give offspring depends on the quality of sperm that is produced by the testes through the process of spermatogenesis and the ability of the reproductive organs to deliver spermatozoa to meet the ovum [4].

Quality of spermatozoa will affect the amount or quantity of spermatozoa produced. The quantity of spermatozoa is influenced by various things such as food, lifestyle, stress, exercise, obesity, illness, and environment that have a bed level of pollution [2,5]. Another factor that causes infertility in the reproductive organs is free radicals. Free radicals are an atom or molecule that has one or more electrons which are unpaired in the outer layer [6]. The source of free radicals comes from the body, for example, autooxidation, or outside the body, for example, air pollution, chemicals, and ultraviolet light. Free radicals are unstable and have high reactivity, resulting in a chain reaction that produces new radical compounds. These chain reactions often cause lipid peroxidation. Lipid damage that occurs in the male reproductive organs can interfere with spermatogenesis and spermatozoa maturation process.

One way to protect sperm cell walls from oxidative damage is to increase antioxidant intake [2]. Antioxidants are compounds that can protect cells from free radical attacks. This is because antioxidant compounds can give electrons to free radical compounds that inhibit oxidation reactions [7]. In addition, antioxidants can also slow down the oxidation reaction and can even repair and reduce oxidative damage due to free radicals $[8,9]$. Considering the side effects of synthetic drugs, many populations in the world are looking for natural treatments that are safe and effective for treating the health problems they face. Several studies found that $80 \%$ of the world population believed in traditional medicine, especially using medicinal plants as their main treatment [10].

Khalal date palm (Phoenix dactylifera L.) is one of the many herbs used for the treatment by Arab countries. Each part of these young dates can be used to treat memory disorders, fever, loss of consciousness, and neurological disorders; to prevent cancer, anti-inflammatory, and antihepatotoxic; and to prevent cardiovascular disorders and degenerative processes that involve oxidative stress. Several studies 
have been conducted; it was found that dates ( $P$. dactylifera L.) are a rich source of antioxidants. The antioxidant activity of dates (P. dactylifera L.) is indicated by the presence of phenolic compounds, flavonoids, and Vitamin $\mathrm{C}$ in them. The number of polyphenol compounds that can be isolated from dates ( $P$. dactylifera L.) ranges between $31 \mathrm{~g}$ and $44 \mathrm{~g}$ depending on the variety [11].

In this study, the results obtained from the administration of khalal date fruit extract will be compared with propolis. Propolis also has antioxidant activity against oxidants and free radicals. The application of propolis aims to prevent the formation of free radicals. Propolis which is a product derived from bees containing caffeic acid phenethyl ester can protect sperm from DNA damage caused by benzo A pyrene and exogenous reactive oxygen species [14]. Research has also been carried out on the effects of propolis on spermatogenesis. The results of in vitro research on ejaculate showed that propolis was proven to be able to improve the efficiency of mitochondrial respiratory; therefore, it was also able to improve sperm motility [12]. Based on the increase in infertility cases in Indonesia and considering the treatment can be done naturally without worrying about the side effects that will be caused, it is necessary to research the anti-infertility effects of ethanol extract of khalal dates with ethanol induction and compare them with propolis preparations that have been shown to improve sperm quality. Induction of ethanol is a way to reduce the production, release, and maturation of spermatozoa in experimental animals. Damage to spermatozoa in mice can be produced by injecting ethanol $2.8 \mathrm{~g} / \mathrm{kg} \mathrm{BB}$, resulting from the conversion of doses from the results of the study [13] to Wistar rats, i.e., $2 \mathrm{~g} / \mathrm{kg} \mathrm{BB}$ intravenously.

\section{MATERIALS AND METHODS}

\section{Tool}

Surgical scissors, animal scales, maintenance cages, watch glass, wipes, Handcsoon: gloves, laboratory equipment, digital cameras, thermos, glass cups, digital scales, Spatel: tounge depressor, mice for eating and drinking, micropipettes, minor surgical equipment, slender needles (gavage needle), disposable syringe $1 \mathrm{ml}$, Petri dish, room for improved Neubauer hemocytometer counters, watch glasses, stationery, surgical board, object glass, microscope, hull sonde, analytic scales, rotary evaporator, measuring cup, water heater, crystal lamp, reagent bottle, drop pipette, filter paper, funnel, Erlenmeyer, goblet, tweezers, and object glasses were used.

\section{MATERIALS}

The materials used in this study were khalal dates (P. dactylifera $\mathrm{L}$ ), Aquadest, $96 \%$ ethanol, Giemsa solution, George's solution, $0.9 \% \mathrm{NaCl}$, and spiritus. The experimental animals used were healthy white male mice (Mus musculus L.) and had never been used for experiments that were 2-3 months old weighing 20-35 g with a sample of 30 tails.

\section{Ethical clearance}

This study was approved by the committee of the research ethics of the Faculty of Medicine, Andalas University.

\section{Treatment of animals}

Twenty-five mice were prepared. Before being treated, mice were acclimatized for 1 week for adjustment. Mice were grouped into five treatment groups, where each group consisted of five mice, and from five treatment groups, there were 1 control group and 4 test groups. The control group was the group that was only given ethanol induction, while the test group was the group given ethanol induction followed by ethanol extract of khalal dates (P. dactylifera $\mathrm{L}$.) at a dose of $140 \mathrm{mg} / \mathrm{kg} \mathrm{BB}, 280 \mathrm{mg} / \mathrm{kg} \mathrm{BB}$, and $560 \mathrm{mg} / \mathrm{kg} \mathrm{BB}$ and propolis at a dose of $1400 \mathrm{mg} / \mathrm{kg} \mathrm{BB}$. First, all groups were given ethanol for 34 consecutive days intraperitoneally. In the test group, in addition to the administration of ethanol induction, on the $18^{\text {th }}$ day, a suspension of ethanol extract of khalal date palm (P. dactylifera L.) and propolis as a comparison were given orally. On the $36^{\text {th }}$ day, laparotomy was performed in mice to retrieve the reproductive organs of male white mice (M. musculus L.) needed for further examination.

\section{Testicle weight calculation}

Mice were treated in a laparotomy, and then, removal of the testis and the right and left vas deferens were removed. Then, the vas deferens is separated from the testis for sperm. Then, the testes from the mice are also taken for weighing. The weight of the testes is weighed on a watch glass with an analytical scale. The weight of an empty watch glass is weighed, and then, the testes are placed on the watch glass and weighed. Testicular weight is obtained by finding the difference between the weight of the watch glass containing the testicles and the weight of an empty watch glass. Then, testicular weight results of mice given treatment were compared with the weight of testis mice positive control.

\section{Taking spermatozoa}

The vas deferens that has been separated from the testis is taken and cuts from the part of the proximal vas deferens (the base of the cauda epididymis) to the distal vas deferens (ejaculatory tubules) $2 \mathrm{~cm}$ long. Then, the spermatozoa that have been removed from the vas deferens by massaging using tweezers are accommodated with $0.9 \% \mathrm{NaCl}$ as much as $0.5 \mathrm{ml}$ on a watch glass (Ermiza, 2012). Then, rinsing the vas deferens part 3 times using $0.25 \mathrm{ml} \mathrm{NaCl} 0.9 \mathrm{ml}$ to ensure that no more spermatozoa remain in the vas deferens. This mixture is called a spermatozoa stock solution.

\section{Spermatozoa analysis}

\section{Examination of the number of spermatozoa}

Taken $90 \mathrm{ml}$ of $0.9 \% \mathrm{NaCl}$ solution and then added with $10 \mathrm{ml}$ of stock solution and put into a microtube. Then, the mixture is taken, and then as much as $5 \mathrm{ml}$ are dropped into the improved Neubauer counting room. Then, the counting room which contains the test solution is covered with cover glass; then, the number of spermatozoa in the counting room is calculated under a microscope. Calculations are carried out under a bright field microscope with a magnification of 400 times. Spermatozoa in 25 small boxes used for counting red blood cells are added together. The total number of spermatozoa is expressed in million $/ \mathrm{ml}$.

\section{Calculation of spermatozoa motility}

This analysis is almost the same with examining the number of spermatozoa, the difference is the observation that focused on calculating the spermatozoa movement, which includes spermatozoa that move fast, slowly and not straight, move in place, and not moving. Furthermore, the percentage of sperm motility was calculated which consisted of the percentage of fast-moving spermatozoa (Grade 4), moving slowly; then, the percentage calculation of spermatozoa can be calculated as follows:

$\%$ sperm Motility $=\frac{n \times \text { score } \times}{\sum n \times \text { grade }} \times 100$

$\mathrm{n}=$ sperm motility

$\sum \mathrm{n}=$ sperm count and not straight (Grade 3), moving in place (Grade 1), and not moving (Grade 0).

\section{Data analysis}

The data obtained were analyzed descriptively. Normally distributed data were analyzed by one-way ANOVA test to determine the effect of ethanolinduction given ethanol extract of khalal dates (P. dactylifera L.) at various doses on the number of spermatozoa, sperm motility, testicular weight, and sexual behavior of male white mice (M. musculus L.). If there are significant differences between treatments, then continue using the Duncan test with a 95\% confidence interval $(\alpha=0.05)$ with SPSS 22 software.

\section{RESULTS}

The administration of the ethanol extract of khalal dates (P. dactylifera L.) and propolis as a comparison showed antifertility activity that was significantly different $(p<0.05)$ on the quality of spermatozoa in male white mice which included number of 
Table 1: Weight of testes and spermatozoa analysis in male white mice (M. musculus L.)

\begin{tabular}{llll}
\hline Doses & $\begin{array}{l}\text { Berat testis } \\
\text { kanan }(\text { g) } \pm \text { SE }\end{array}$ & $\begin{array}{l}\text { Berat testis } \\
\text { Kiri (g) } \pm \text { SE }\end{array}$ & $\begin{array}{l}\text { Jumlah spermatozoa } \\
\text { (juta/ml) } \pm \text { SE }\end{array}$ \\
\hline Control & $0.112 \pm 0.005$ & $0.108 \pm 0.005^{\mathrm{a}}$ & $\begin{array}{l}\text { Rata-rata \% motilitas } \\
\text { spermatozoa } \pm \text { SE }\end{array}$ \\
Dose $140 \mathrm{mg} / \mathrm{kg} \mathrm{BB}$ & $0.131 \pm 0.005$ & $0.121 \pm 0.004^{\mathrm{ab}}$ & $238.8 \pm 84.05^{\mathrm{a}}$ \\
Dose $280 \mathrm{mg} / \mathrm{kg} \mathrm{BB}$ & $0.136 \pm 0.007$ & $0.131 \pm 0.005^{\mathrm{bc}}$ & $393 \pm 86.98^{\mathrm{ab}}$ \\
Dose $560 \mathrm{mg} / \mathrm{kg} \mathrm{BB}$ & $0.142 \pm 0.008$ & $0.140 \pm 0.008^{\mathrm{c}}$ & $479 \pm 79.18^{\mathrm{b}}$ \\
Propolis & $0.136 \pm 0.003$ & $0.136 \pm 0.003^{\mathrm{bc}}$ & $38.38 \pm 4.76^{\mathrm{b}}$ \\
\hline
\end{tabular}

SE: Standar error, M. musculus: Mus musculus, Different alphabets $(\mathrm{a}, \mathrm{b}, \mathrm{ab}, \mathrm{c}, \mathrm{bc}$ ) in the same column or row mean that there are significant differences ( $<<0.05$ )

spermatozoa, sperm motility, and testicular weight of male white mice (M. musculus L.). There are 5 treatment groups, which are group with dose of $560 \mathrm{mg} / \mathrm{kg} \mathrm{BW}, 280 \mathrm{mg} / \mathrm{kg} \mathrm{BW}, 140 \mathrm{mg} / \mathrm{kg} \mathrm{BW}$, group with propolis, and control. Testicular weight of male white mice increased with increasing doses and propolis showed the second highest increase in testicular weight after a dose of $560 \mathrm{mg} / \mathrm{kg}$ BW as shown in Table 1. Meanwhile, the number of spermatozoa of male white mice also increased with increasing doses where propolis was in the third position which showed an increase in the number of spermatozoa as shown in Table 1, while the percentage of sperm motility also showed an increase with increasing dose and propolis showed the highest percentage of motility after the dose of $560 \mathrm{mg} / \mathrm{kg} \mathrm{BB}$ and $280 \mathrm{mg} / \mathrm{kg}$ BB as shown in Table 1.

\section{DISCUSSION}

In this study, we can see the protective ability of ethanol extract of khalal dates $(P$. dactylifera $L$.) and propolis as a comparison in mice reproductive organs that have been given ethanol induction so that it influenced the quality of spermatozoa to the quality of spermatozoa produced. Administration of ethanol induction will cause spermatozoa production to be inhibited. The administration of ethanol extract of khalal dates ( $P$. dactylifera L.) containing compounds that have antioxidant activity can provide protection against reproductive organ damage in male white mice (M. musculus L.). Antioxidant compounds contained in dates can prevent cell damage that occurs due to oxidative stress in spermatogenic cells in the seminiferous tubules and Leydig cells in the testes [14].

Based on the research that has been done, there are differences in results between groups that were only given ethanol induction or a control group with the group given ethanol induction coupled with the ethanol extract of khalal dates $(P$. dactylifera $L$.) and propolis as a comparison or test group. The differences that appear indicate that there is a decrease in sperm quality in the form of a decrease in the number of spermatozoa, the percentage of sperm motility and testicular weight of mice from the test group to the control group. This is due to the effects of ethanol which is a free radical compound that causes oxidation chain reactions which often cause lipid peroxidation and lead to cell damage which can inhibit spermatozoa production and maturation [15]. Observations made on the weight of testicular mice showed changes and increased testicular weight from the control group to the test group. Administration of ethanol induction can cause a decrease in testicular weight [16]. In testicular organs of mice, the results of ethanol metabolism can cause damage to Leydig cells in the form of a decrease in cell volume, resulting in a decrease in testosterone production, a hormone that is needed in the process of maturation of the spermatozoa in the epididymis. In Sertoli cells, it can lead to enlargement of vacuoles caused by swelling of cysternae in the smooth endoplasmic reticulum. Ethanol can also cause a smaller diameter of the seminiferous tubules and enlarged lumen of the tubules. Disorders of Leydig cells, Sertoli cells, and seminiferous tubules can reduce the number of germ cells and testicular atrophy or decrease in testicular weight [16]. This supports the results of the study that inducing ethanol can reduce the weight of testicular mice, so the administration of ethanol extracts of khalal dates (P. dactylifera L.) and propolis as a comparison can improve damage to the testicular organs of mice as indicated by an increase in testicular weight in mice.
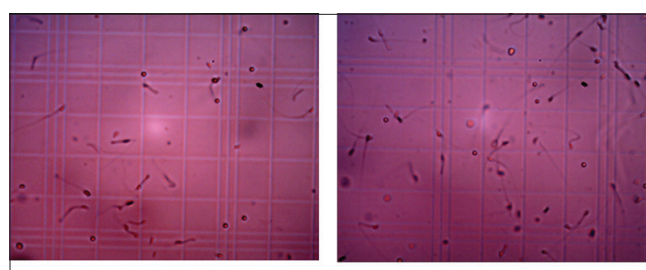

Control Group

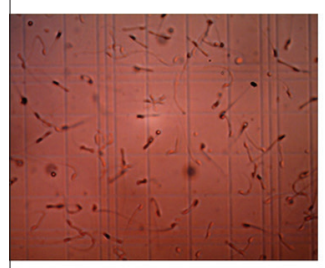

Treatment Group 1 (extract dose $140 \mathrm{mg} / \mathrm{kg} \mathrm{BW})$
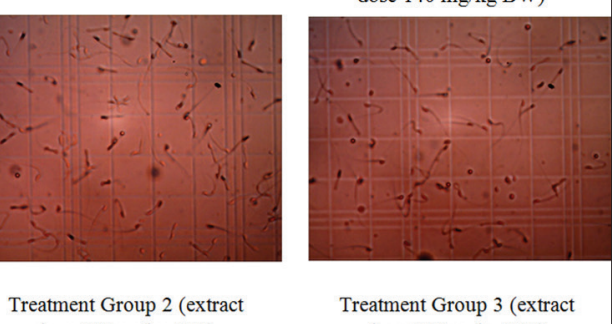

dose $280 \mathrm{mg} / \mathrm{kg}$ BW)

Treatment Group 3 (extract dose $560 \mathrm{mg} / \mathrm{kg} \mathrm{BW}$ )

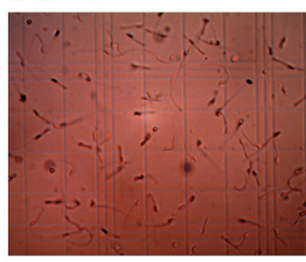

Treatment Group 4 (propolis dose $1400 \mathrm{mg} / \mathrm{kg} \mathrm{BW}$ )

Fig. 1: The appearance of spermatozoa in the count room hemocytometer improved Neubauer

In observing the number of spermatozoa, there are more spermatozoa that die compared to the number of living spermatozoa (Fig. 1). This is caused by the administration of ethanol induction (free radicals) which can attack normal sperm cells so that they will form new free radical compounds in large quantities. The presence of free radicals will cause morphological changes from normal cells to abnormal even until cell death occurs [17]. This is the reason why many spermatozoa die compared to the living. The length of time that a sperm can survive is influenced by several factors such as temperature, $\mathrm{pH}$ and osmolarity of the extracellular environment. Osmolarity has a very important role in determining the duration of spermatozoa which can move and survive. Spermatozoa exposed to low osmotic pressure conditions for a long time can cause disruption of the plasma membrane, causing swelling in the flagellum and mitochondria so that it ends with cell death $[18,19]$.

\section{CONCLUSION}

The administration of the ethanol extract of khalal dates (P. dactylifera L.) and propolis as a comparison gave anti-infertility activity which was significantly different from the quality of spermatozoa of male white mice (M. musculus L.) which was characterized by an increase in the number of spermatozoa, the percentage of sperm motility, and the weight of the left testis.

From male white mice, but did not give a significant effect on the weight of the right testis in male white mice (M. musculus L.) which had been 
induced by ethanol. The administration of ethanol extract of khalal dates (P. dactylifera L.) caused an increase in the number of spermatozoa, percentage of sperm motility, and testicular weight of male white mice $(M$. musculus L.) along with the increased dose given. The optimum activity was obtained at a dose of $560 \mathrm{mg} / \mathrm{kg}$ BW while the provision of propolis is it has a medium effect on the quality and weight of testicular mice.

\section{ACKNOWLEDGMENTS}

Our gratitude goes to those who had helped a lot, especially the LPPM BOPTN Andalas University, who helped to fund this research from the beginning until the research was completed and registered in the AJPCR indexed Scopus Journal.

\section{AUTHORS' CONTRIBUTIONS}

All authors have equal contribution toward this manuscript, the study conception, and experimental design by Dwisari D and Ria A, plant identification by Skunda D, analysis and interpretation of statistical data by Almahdy, and interpretation of histological data by Biomechy $\mathrm{OP}$ and Noverial.

\section{CONFLICTS OF INTEREST}

There are no conflicts of interest.

\section{REFERENCES}

1. Wiweko B, Upik A, Sylvia D, Hilma P. Distribution of stress level among infertility patients. Middle East Fertil Soc J 2017;30:1-4

2. Saryono S, Retnani H, Santoso D. Seduhan biji kurma (Phoenix dactylifera) memperkuat membran sel sperma untuk menurunkan kadar malondialdehid. J Ners 2015;10:355-9.

3. Jungwirth A, Aleksander G, Herman T, Thorsten D, Zsolt K, Gert D, et al. European association of urology guidelines on male infertility: The 2012 update. Eur Urol 2012;62:324-32.

4. Lotti F, Corona G, Rastrelli G, Forti G, Jannini EA, Maggi M, et al. Clinical correlates of erectile dysfunction and premature ejaculation in men with couple infertility. J Sex Med 2012;9:2698-707.

5. Emanuele MA, Emanuele NA. Alkohol's effect on male reproduction. Alkohol Res Health 1998;22:195-201.
6. Halliwell B, Whiteman M. Measuring reactive species and oxidative damage in vivo and in cell culture: How should you do it and what do the results mean? Br J Pharm 2004;142:231-55.

7. Percival M. Antioxidant. Clin Nutr Insight 1996;10:1-4.

8. Usoh IF, Akpan EJ, Etim EO, Farombi EO. Antioxidant action of dried flower extract of Hibiscus sabdariffa 1 on soddium arsenite - Induced oxidative stress in rats. Pak J Nutr 2005;4:135-41.

9. Winarsi H. Antioksidan Alami Dan Radikal Bebas. Yogyakarta: Penerbit Kanisius; 2007.

10. Pujari RR, Neeraj SV, Prasad AT. Protective effects of Phoenix dactylifera againts oxidative stress and neuronal damage induced by global cerebral ischemia in rats. Biomed Aging Pathol 2013;3:75-81.

11. Abdelaziz DH, Ali SA. The protective effect of Phoenix dactylifera $\mathrm{L}$ seeds against $\mathrm{CCl} 4$-induced hepatotoxicity in rats. J Ethnopharmacol 2014;155:736-43.

12. Cedikova M, Miklikova M, Stachova L. Effect of The Czech propolis on sperm mitochondrial function. Evid Based Complement Alternat Med 2014;2014:248-768.

13. Ganaraja B, Crystal D, Vijayalakshmi BM, Nayanatara AK, Bhat MR, Ramaswamy C. Use of Vitamin C on effect of ethanol induced lipid peroxidation in various tissue, sperm count, and morphology in the wistar rats. J Chin Clin Med 2008;3:1-3.

14. Russo A, Acquaviva R, Campisi A, Sorrenti V, Di Giacomo C, Virgata $\mathrm{G}$, et al. Bioflavonoids as antiradicals, antioxidants and DNA cleavage protectors. Cell Biol Toxicol 2000;16:91-8.

15. Mohamed NA, Ahmed OM, Hozayen WG, Ahmed MA. Ameliorative effects of bee pollen and date palm pollen on the glycemic state and male sexual dysfunctions in streptozotocin-induced diabetic wistar rats. Biomed Pharmacother 2018;97:9-18.

16. Purwaningsih E. Spermatozoa morphology: Is there any correlation with successful pregnancy. J Kedokteran Yarsi 1996;4:54-63.

17. Sutarni S. Sari Neurotoksikologi. Jakarta: Pustaka Cendekia Press; 2007.

18. David I, Kohnke P, Lagriffoul G, Praud O, Plouarboué F, Degond P, et al. Mass sperm motility is associated with fertility in sheep. Anim Reprod Sci 2015;161:75-81.

19. Della Togna G, Gratwicke B, Evans M, Augustine L, Chia H, Bronikowski $\mathrm{E}$, et al. Influence of extracellular environment on the motility and structural properties of spermatozoa collected from hormonally stimulated panamanian golden frog (Atelopus zeteki). Theriogenology 2018;108:153-60. 